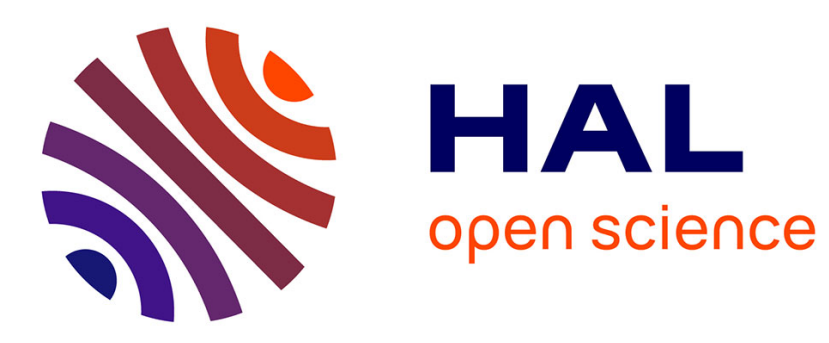

\title{
Synthesis of novel photoluminescent pyridinium-betaine-type molecules
}

Ammar Hassoun, Amina Benchohra, Omar Abou Khaled, Dalila Seghouane, Jamal Moussa

\section{- To cite this version:}

Ammar Hassoun, Amina Benchohra, Omar Abou Khaled, Dalila Seghouane, Jamal Moussa. Synthesis of novel photoluminescent pyridinium-betaine-type molecules. Chemical Monthly $=$ Monatshefte für Chemie, 2020, 151, pp.799-806. 10.1007/s00706-020-02591-9 . hal-02879908

\section{HAL Id: hal-02879908 https: / hal.sorbonne-universite.fr/hal-02879908}

Submitted on 24 Jun 2020

HAL is a multi-disciplinary open access archive for the deposit and dissemination of scientific research documents, whether they are published or not. The documents may come from teaching and research institutions in France or abroad, or from public or private research centers.
L'archive ouverte pluridisciplinaire HAL, est destinée au dépôt et à la diffusion de documents scientifiques de niveau recherche, publiés ou non, émanant des établissements d'enseignement et de recherche français ou étrangers, des laboratoires publics ou privés. 
1 Synthesis of novel photoluminescent pyridinium-betaine type molecules

\section{Seghouane • Jamal Moussa $\bowtie$}

5 Received: ......./Accepted ...

6

7 Abstract A series of pyridinium-betaine like molecules has been reported;

8 one family of molecules is built with a benzimidazole core and a second

9 one with a pyrimidine moiety. The title compounds were prepared by

10 mixing 2-chlorobenzimidazole or 2-bromopyrimidine with the

11 corresponding pyridines (pyridine, 4-tert-butylpyridine, 4-hydroxypyridine,

12 potassium 4-trifluoroboratepyridine, 4-dimethylaminopyridine) in

13 acetonitrile or DMSO at high temperatures. The novel compounds were

14 characterized by spectroscopic methods. The UV-Vis. and fluorescence

15 features are reported as well. Preliminary photoluminescence results

16 showed broadband emissions as common feature ascribed to the

17 compounds containing benzimidazole ring. Some of the spectra nearly span

18 over the whole visible spectral range, which pave the way to real

19 opportunities to design single-component panchromatic emitters.

20 Keywords Pyridinium $\bullet$ Betaines $\bullet$ Fluorescence $\bullet$ Absorption

21

$22 \square$ Dr. Jamal Moussa

23 jamal.moussa@sorbonne-universite.fr 
1 Institut Parisien de Chimie Moléculaire UMR 8232, Sorbonne Université, 4 2 place Jussieu, 75252 Paris cedex 05, France.

3

4

5 


\section{Introduction}

2 Pyridinium-betaine dyes are a fascinating class of compounds,

3 especially due to their exceptional photophysical properties related to the

4 presence of low-lying intramolecular charge-transfer (CT) excited states.

5 [1-4] In particular, these compounds usually exhibit large negative

6 solvatochromism because of a dramatic reduction of the dipole moment

7 between the ground and the excited states; this has led to the development

8 of general methods for solvents polarity measurements.[5] An important

9 other feature is a large first-order hyperpolarizability and thus large non-

10 linear optical response resulting from the dipole moment change which

11 makes these molecules very attractive compounds for NLO applications.[6-

12 7]

13 On the other hand since the pioneering work by the groups of

14 Breslow,[8] Wanzlick[9] and Öfele[10] and the isolation of the first stable

15 metal free carbenes by Bertrand et al.[11] and Arduengo et al.[12] the

16 chemistry of N-heterocyclic carbenes has developed remarkably because of

17 their peculiar stereoelectronic properties especially their exceptional $\sigma$ -

18 donor capacity in catalytically active metal complexes.[13] Meanwhile,

19 several classes of $\mathrm{N}$-heterocyclic carbenes have been discovered, among

20 others pyridylidenes remain relatively unexplored as a result of tedious and

21 non-general synthetic methods of such species.[14-19] 
1 Although the chemistry of N-heterocyclic carbenes (NHCs) and the

2 chemistry of heterocyclic mesomeric betaines (MB) have a common area,

3 there are very few compounds exhibiting both functionalities. Betaines are

4 molecules that can be represented by only one dipolar canonical formula in

5 which the positive and negative charges are delocalized within a common

$6 \pi$-electron system. There are several relationships that link the salts of $N$ -

7 heterocyclic carbenes and mesomeric betaines, for instance interesting

8 results have been recently reported by Schmidtt et al. with pyridinium-2-

9 carboxylates that evolve to $N$-heterocyclic carbenes.[20]

10 We describe here a simple synthesis of pyridinium-betaine compounds in

11 the view to utilize them later as bidentate chelating $N^{\wedge} C$ heteraryl-

12 pyridylidene ligands. The target compounds are shown in Figure 1; We

13 believe that this type of molecules represents a real opportunity for the

14 development of a new class of bidentate ligands exhibiting rare

15 pyridylidene centres combined with other nitrogen or heteroatom donors to

16 provide unprecedented transition metal complexes with multiple potential

17 applications in luminescent materials or catalysis for example. The

18 chemistry and the results of such compounds will be reported in the near

19 future and in the adequate journals. 
<smiles></smiles>

(1)<smiles></smiles><smiles>O=c1ccn(-c2nc3ccccc3[nH]2)cc1</smiles><smiles>[Se]c1cc[n+](-c2nc3ccccc3[nH]2)cc1</smiles><smiles></smiles><smiles>O=c1ccn(-c2ncccn2)cc1</smiles><smiles>[Sb]c1cc[n+](-c2ncccn2)cc1</smiles><smiles></smiles>
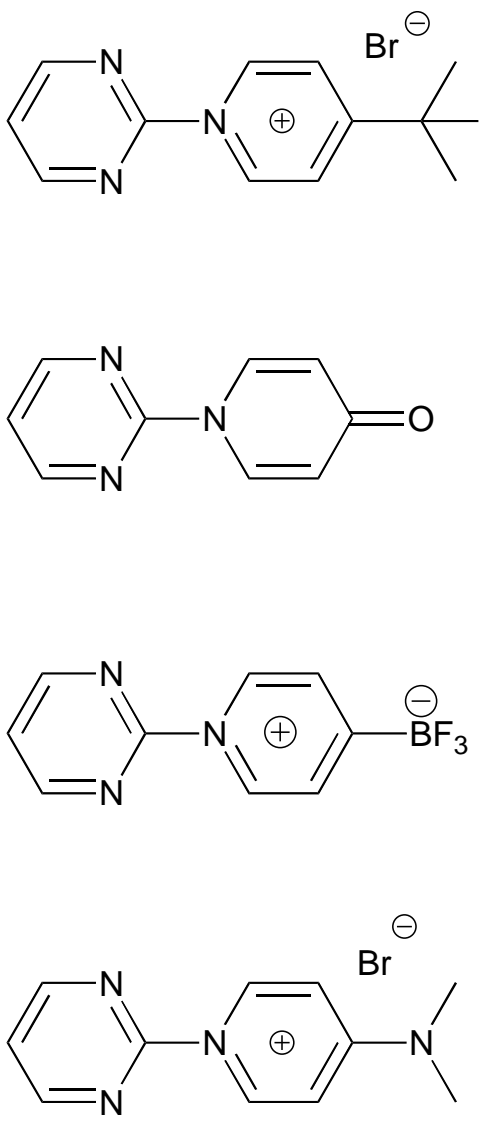

2 Figure 1: Novel pyridinium-benzimidazole and pyridinium-pyrimidine 3 scaffolds.

4

\section{$5 \quad$ Results and Discussion}

\section{Synthesis and characterization}

7 The synthetic routes leading to compounds $\mathbf{1 - 5}$ are depicted in scheme 1 .

8 Treatment of 2-chlorobenzimidazole with an excess of pyridine in

9 acetonitrile under reflux and subsequent reaction work-up provided the 
1 target molecule in good yield. The resulting compound is obtained upon

2 substitution of the chloride atom by pyridine and consists of a

3 benzimidazole moiety linked through the $\mathrm{C} 2$ carbon to the nitrogen of the

4 pyridine providing a pyridinum chemical structure. The unreacted 2-

5 chlorobenzimidazole crystalizes as white needles and is separated by

6 filtration on a sintered glass funnel. Then treatment with cesium carbonate

7 provided compound $\mathbf{1}$ reproductively in good yields. Identification of the

8 compound was unambiguously achieved by spectroscopic methods. For

9 instance, the ${ }^{1} \mathrm{H}-\mathrm{NMR}$ spectrum of 2-pyridinumbenzimidazole (1) in

$10 \mathrm{CD}_{3} \mathrm{CN}$ shows a series of signals in the aromatic region due to the protons

11 of the pyridinium and the benzimidazole moieties. A typical set of signals

12 of an AA'BB' system attributable to the benzimidazole protons is

13 observable at $\delta=7.08 \mathrm{ppm}$ and $\delta=7.57 \mathrm{ppm}$, finally two triplets and one

14 doublets are visible at $\delta=8.06 \mathrm{ppm}, \delta=8.48 \mathrm{ppm}$ and $\delta=9.99 \mathrm{ppm}$. This

15 compound was described in the literature using a different synthesis

16 method without NMR characterization.[21] 


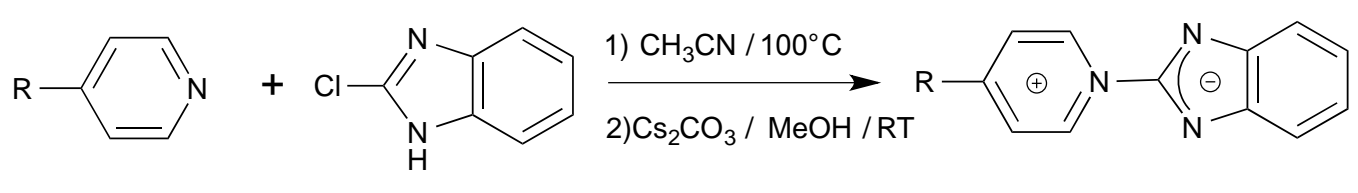

$$
\mathrm{R}=-\mathrm{H}, \mathrm{t}-\mathrm{Bu}, \mathrm{NMe}_{2} \quad \mathrm{R}=-\mathrm{H}(\mathbf{1}),-\mathrm{t}-\mathrm{Bu}(\mathbf{2}),-\mathrm{NMe}_{2}(\mathbf{5},
$$

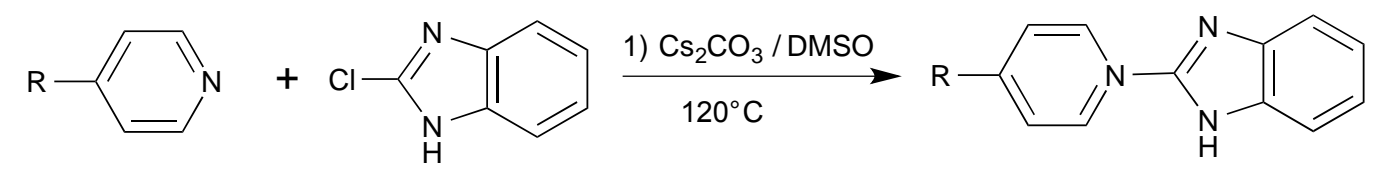

$1 \quad \mathrm{R}=-\mathrm{OH},-\mathrm{BF}_{3}-$

$$
\mathrm{R}=-\mathrm{O}(\mathbf{3}),-\mathrm{BF}_{3}(\mathbf{4})
$$

2 Scheme 1: Synthesis of the pyridinium-betaine molecules with the

3 benzimidazole core (1-5)

4 Under the reaction conditions for the preparation of compound $\mathbf{1}$, 5 using 4-tert-butylpyridine instead of pyridine gave compound 2. The 6 molecular weight of the target molecule was determined by mass 7 spectroscopy (252.1505 g.mol ${ }^{-1}$ ) and further characterization by ${ }^{1} \mathrm{H}-$ and $8{ }^{13} \mathrm{C}$-NMR spectroscopy confirmed the identity of the novel compound 2. 9 (see experimental part for details).

10 Using 4-hydroxypyridne instead of pyridine or 4-tert-buthylpyridine

11 in these reaction conditions did not allow obtaining the target compound.

12 However using DMSO as solvent and under high temperature conditions,

13 in presence of sodium or caesium carbonate provided finally the desired

14 molecule $\mathbf{3}$ in good yield. Molecule $\mathbf{3}$ is a pyridone core linked through the

15 nitrogen to $\mathrm{C} 2$ carbon of the benzimidazole moiety. It was identified by 
1 NMR and infrared spectroscopy techniques. The molecular weight of the

2 target molecule was determined by mass spectroscopy (234.0638 g.mol $\left.{ }^{-1}\right)$.

3 (see experimental part for details). These reaction conditions using 4-

4 trifluoroboratepyridine instead of 4-hydroxypyridine but in absence of

5 carbonates provided the zwiterrion 4 in good yield. Identification of the

6 compound was unambiguously achieved by ${ }^{1} \mathrm{H}-$ and ${ }^{13} \mathrm{C}-\mathrm{NMR}$ and infrared

7 spectroscopic methods. Evidence of the molecular weight of the molecule

8 emanates from mass spectroscopy (262.0761 g.mol ${ }^{-1}$ ). (Structural details

9 are given in the experimental part)

10 The last molecule of this series is prepared by reaction 2-

11 chlorobenzimidazole with 4-dimethylaminopyridine using the experimental

12 conditions to prepare compound $\mathbf{3}$. The target compound $\mathbf{5}$ is obtained in

13 good yield. The identity of the new compound was clearly ascertained by

$14{ }^{1}$ H-NMR and infrared spectroscopic methods. Confirmation of the

15 molecular weight of the isolated molecule is obtained from mass

16 spectroscopy $\left(239.1295\right.$ g.mol $\left.{ }^{-1}\right)$.

17 We then decided to prepare analogous compounds of $\mathbf{1 - 5}$ exhibiting a 18 pyrimidine core instead of the benzimidazole moiety. The desired novel 19 compounds consist of a pyridinium moiety and a pyrimidine part that is 20 expected to be more electron-withdrawing than a benzimidazole ring which 21 might have a profound impact on the electronic properties of the target 
1 final molecules and later on the metal complexes. The synthetic routes 2 leading to compounds 6-10 are depicted in scheme 2.
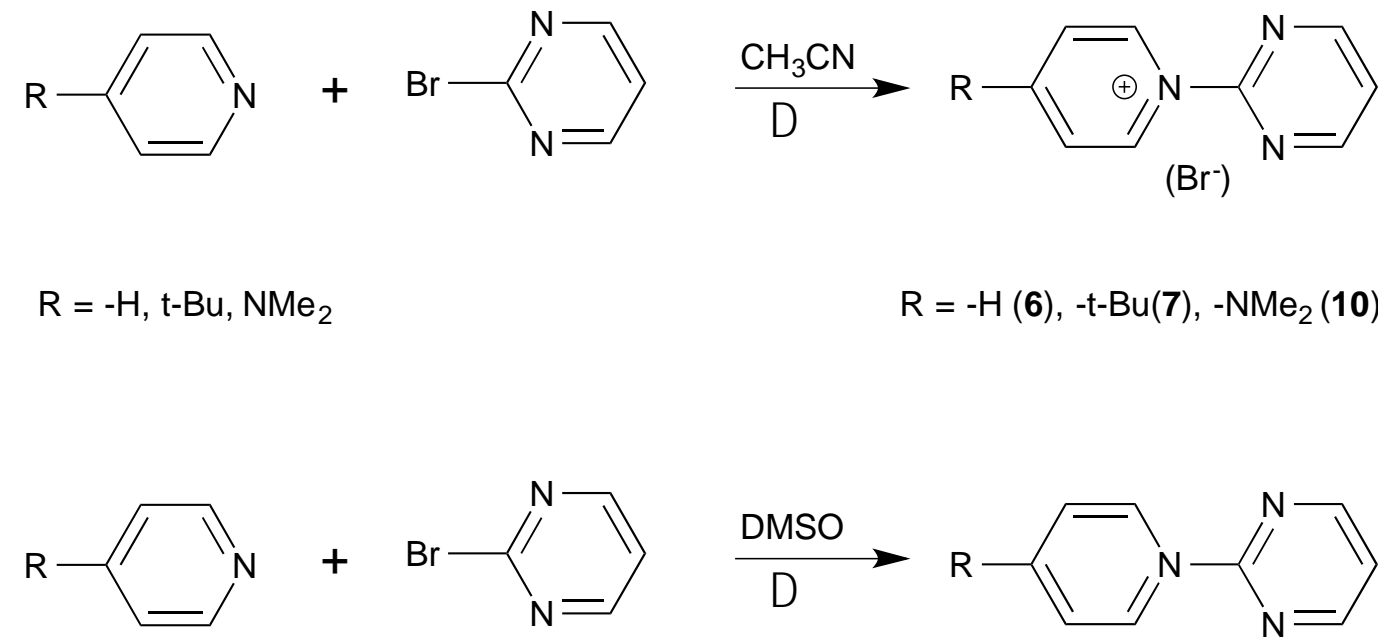

$3 \mathrm{R}=-\mathrm{OH}\left(+\mathrm{Na}_{2} \mathrm{CO}_{3}\right),-\mathrm{BF}_{3}^{-}$

$$
\mathrm{R}=\mathrm{O}(\mathbf{8}),-\mathrm{BF}_{3}^{-}(\mathbf{9})
$$

4 Scheme 2: Synthetic routes to the novel compounds 6-10 based on

5 the pyrimidine core

For instance when 2-bromopyrimidine is reacted with pyridine, the

7 pyridine nitrogen displaces the bromine atom; an interesting cationic

8 compound with a pyridinium core linked by the nitrogen atom to $\mathrm{C} 2$ carbon

9 of a pyrimidine moiety is obtained in good yield. The ${ }^{1} \mathrm{H}-\mathrm{NMR}$ spectrum of

10 compound $\mathbf{6}$ exhibits a set of signals in the aromatic region. A doublet at $\delta$

$11=9.12 \mathrm{ppm}$ and a triplet at $\delta=7.86 \mathrm{ppm}$ are due to the pyrimidine moiety.

12 Four other multiplets are observed due to the pyridinium core. Additional

13 evidence of the molecular weight of the isolated molecule is given by mass 14 spectroscopy $\left(158.0712 \mathrm{~g} \cdot \mathrm{mol}^{-1}\right)$. 
2 provided upon reaction workup compound 7 in good yield. Confirmation of

3 the molecular weight of the isolated molecule is given by mass 4 spectroscopy $\left(214.1347\right.$ g.mol $\left.{ }^{-1}\right)$. The identity of compound 7 was

5 confirmed by ${ }^{1} \mathrm{H}-\mathrm{NMR},{ }^{13} \mathrm{C}-\mathrm{NMR}$ and infrared spectroscopic methods.

6 (Structural details are given in the experimental part).

7 Similarly to the fist series with the benzimidazole moiety, reaction of

8 4-hydroxypyridine with 2-bromopyrimidine in acetonitrile did not offer the

9 target compound. However in the presence of sodium carbonate in hot

10 DMSO the target compound 7 was obtained in good yields. Additional

11 evidence of the molecular weight of the isolated molecule is given by mass

12 spectroscopy (196.0483 g.mol ${ }^{-1}$ ). Compounds $\mathbf{9}$ and $\mathbf{1 0}$ were obtained

13 under similar reaction conditions in good yields.

14 Having prepared these two families of compounds we decided to 15 explore their absorption and emission properties since some of the 16 molecules seemed to be highly luminescent under the UV lamp. 17 Furthermore, as mentioned in the introduction we plan to use these 18 compounds as ligands with transition metals so such a study is relevant to

19 further comparison purposes.

\section{UV-Vis. absorption and emission properties}


1 The UV-Vis. spectra of all compounds were recorded in acetonitrile

2 solutions at $\mathrm{C} \approx 10^{-5} \mathrm{M}$. Spectra of compounds of the first family with the

3 benzimidazole core are assembled in Figure 2. All spectra exhibit a high-

4 energy absorption band with high molar absorptivity molar values typical

5 of $\pi-\pi *$ transitions. Distinct additional charge transfer type transitions at

6 lower energy are visible for compounds 1, 2 and 4. The spectra of

7 molecules $\mathbf{3}$ and $\mathbf{5}$ don't seem to clearly exhibit such charge transfer

8 absorptions, maybe occurring at high energies thus overlapped with the

$9 \pi-\pi *$ transitions, tails on the high energy transitions are however visible.

10 These assignments are in good agreement with the experimental and

11 theoretical studies on the model compound 1.[1a] In particular the authors

12 have shown that the intramolecular charge transfer band in compound $\mathbf{1}$

13 was hypsochromically shifted from toluene to THF and acetonitrile. We

14 have checked the charge transfer character of compounds 2 and 4 by

15 recording the UV-vis. absorption spectra in dichloromethane. Both

16 compounds 2 and 4 exhibited blue shifts from dichloromethane to

17 acetonitrile of $18 \mathrm{~nm}$ and $14 \mathrm{~nm}$ respectively. (The spectra are provided in

18 the supplementary section). Compounds $\mathbf{2 - 1 0}$ are not described in the

19 literature but the close similarity of the data with those of compound $\mathbf{1}$ are 20 in favour of the given assignments. 


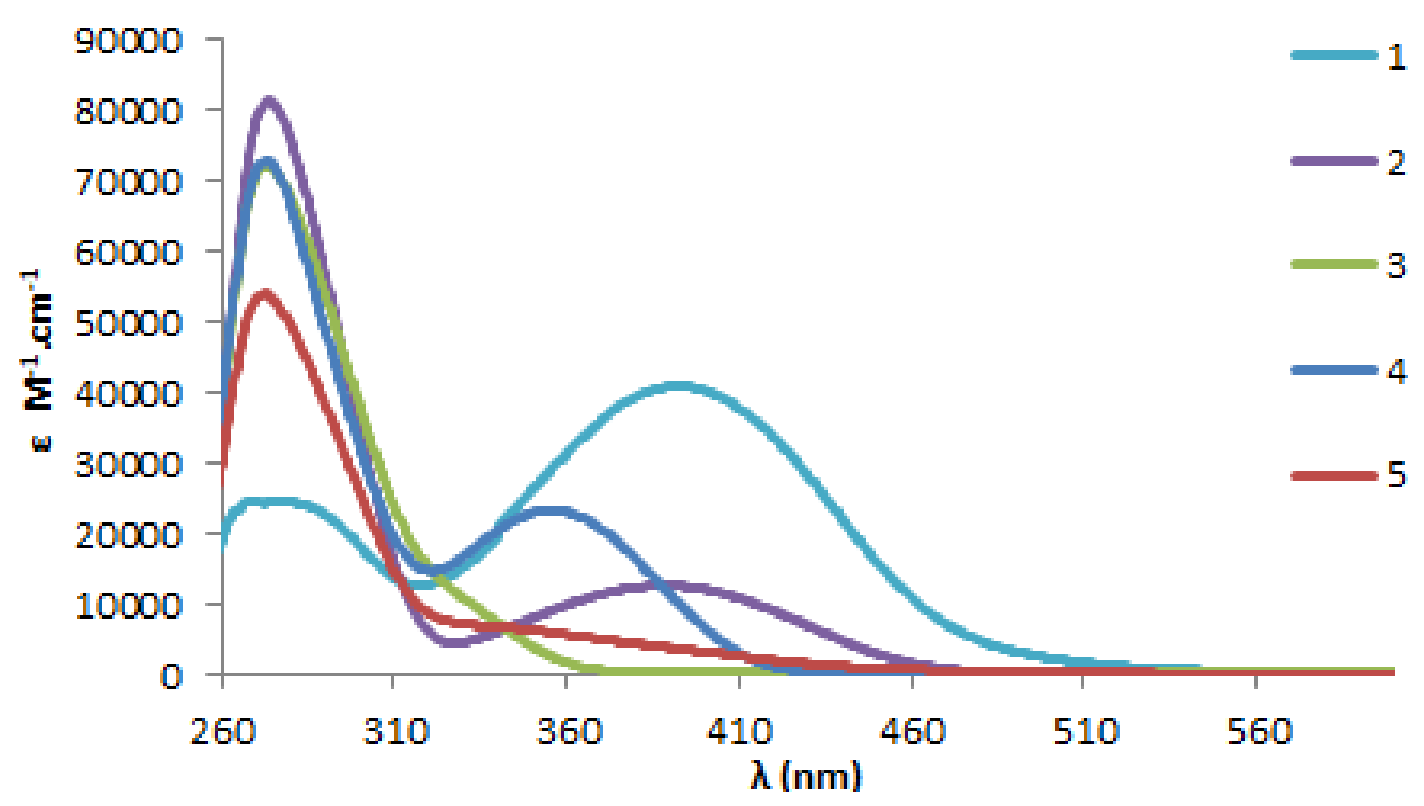

2 Figure 2: Absorption spectra of compounds 1-5 in acetonitrile The UV-Vis. absorption spectra of compounds of the second family

4 with the pyrimidine core (6-10) recorded in acetonitrile are shown in

5 Figure 3 and the data are assembled in table 1. All spectra exhibit a high

6 energy absorption transition around $270 \mathrm{~nm}$ with high molar absorptivity

7 molar values typical of $\pi-\pi *$ transitions with the exception of compound

$8 \mathbf{1 0}$ which shows a significantly lower energy absorption at $320 \mathrm{~nm}$. Within

9 this family no charge transfer type transitions are detectable. 


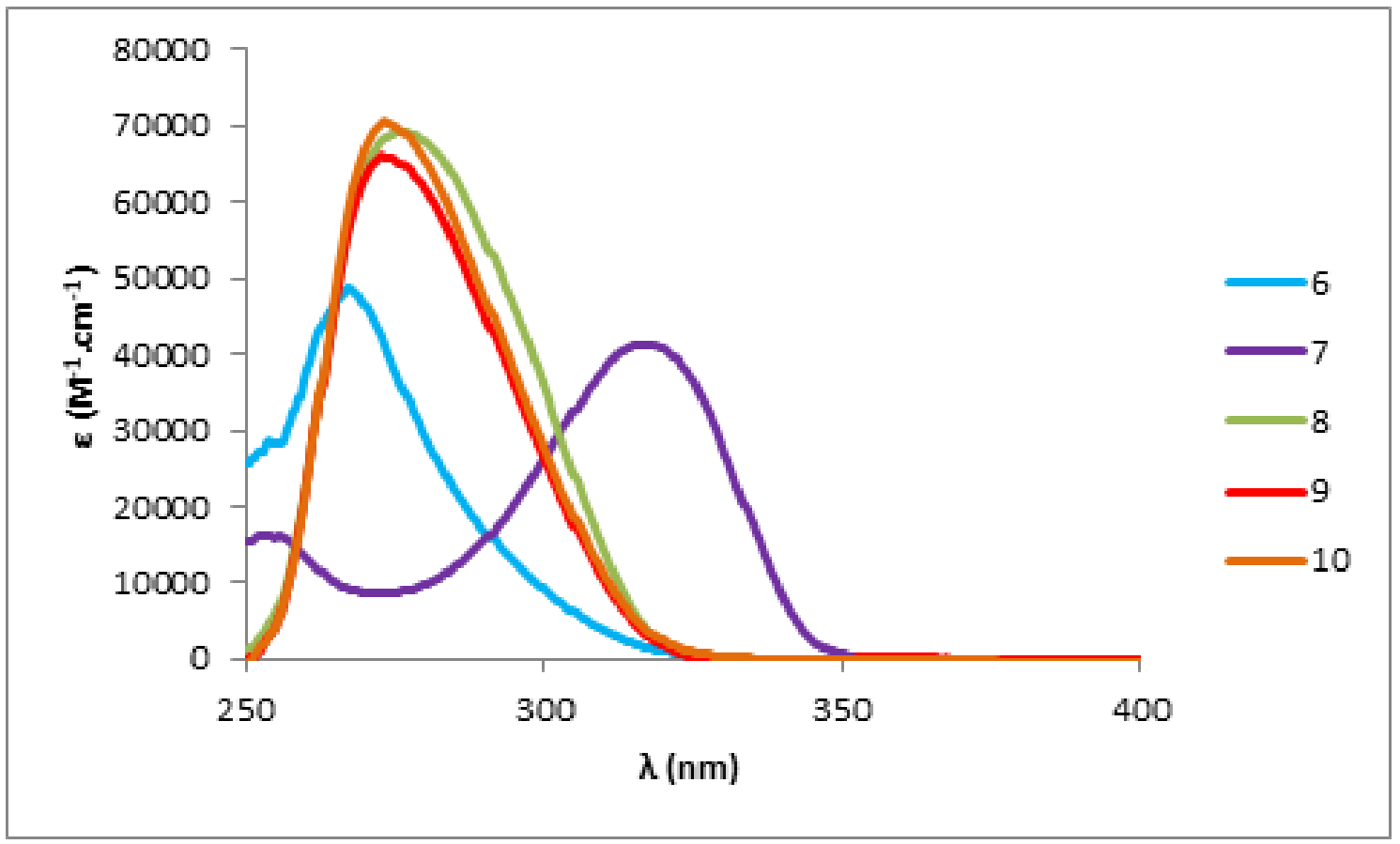

2 Figure 3: Absorption spectra of compounds 6-10 in acetonitrile 3

4 Table 1: UV-Vis. absorption data for compounds 1-10

\begin{tabular}{lll} 
& $\lambda_{\text {abs }}(\mathrm{nm})$ & $\varepsilon\left(\mathrm{mol}^{-1} . \mathrm{L}_{\mathrm{cm}} \mathrm{cm}^{-1}\right) \times 10^{4}$ \\
\hline $\mathbf{1}$ & $269 ; 392$ & $2.47 ; 4.09$ \\
$\mathbf{2}$ & $273 ; 388$ & $8.11 ; 1.27$ \\
$\mathbf{3}$ & 273 & 7.21 \\
$\mathbf{4}$ & $273 ; 355$ & $7.29 ; 2.34$ \\
$\mathbf{5}$ & 272 & 5.39 \\
$\mathbf{6}$ & 267 & 4.87 \\
$\mathbf{7}$ & 317 & 4.13 \\
$\mathbf{8}$ & 277 & 6.91 \\
$\mathbf{9}$ & 273 & 6.59 \\
$\mathbf{1 0}$ & 273 & 7.04
\end{tabular}

6 Photoluminescence spectra of all compounds were recorded in air

7 equilibrated dichloromethane solutions at $\mathrm{C} \approx 10^{-5} \mathrm{M}$. Compounds 6-10 did 8 not exhibit any emission upon excitations in the 300-340 nm. In stark 9 contrast, solutions of compounds $\mathbf{1 - 5}$ exhibit relatively intense emissions 10 upon excitation wavelengths in the range $350-400 \mathrm{~nm}$. The spectra are 
1 presented in figure 4. These data are only qualitative since our goal is to

2 use these compounds to prepare pyridylidene metal complexes as

3 mentioned in the introduction. The parent compound $\mathbf{1}$ was found to exhibit

4 an emission at $\lambda_{\max }=687 \mathrm{~nm}$ in acetonitrile with a blue shift in THF

5 solution at $\lambda_{\max }=675 \mathrm{~nm}$ and in toluene at $\lambda_{\max }=669 \mathrm{~nm}$, we found this

6 emission to be at $\lambda_{\max }=647 \mathrm{~nm}$ in dicholormethane solution at room

7 temperature. Molecule 2 exhibits a similar emission band at $\lambda_{\max }=627 \mathrm{~nm}$

8 in dichloromethane slightly blue shifted in comparison to the parent

9 compound $\mathbf{1}$ due to presence of the tert-butyl- group. The pyridone

10 derivative $\mathbf{3}$ has an interesting UV-blue emission while compounds $\mathbf{4}$ and $\mathbf{5}$

11 exhibit very unusual broad emission bands covering a wide region of the

12 visible spectrum (400-680/690 nm). These unusual broad emission bands

13 seem to be the result of a dual emission which make these molecules

14 interesting candidates to design single-component panchromatic emitters.

15 To make sure that emissions do not arise from small highly emitting

16 impurities, the excitation spectrum has been recorded in the excitation

17 wavelengths range and fits well to the absorption spectrum in each case.

18 White-light emission from a single component is quite rare in the literature;

19 discovery of powerful molecules in this field would be of real application

20 potential in lightening devices. Such behaviour in compounds $\mathbf{4}$ and $\mathbf{5}$ is

21 very peculiar, as far as we are aware there is very few examples displaying 
1 white light emission from a single-component described in the

2 literature.[22-23] White light emission is usually obtained by combination

3 of three different components (blue, green and red emitters), which makes

4 the devices preparation and durability a complicated task.[24-26]

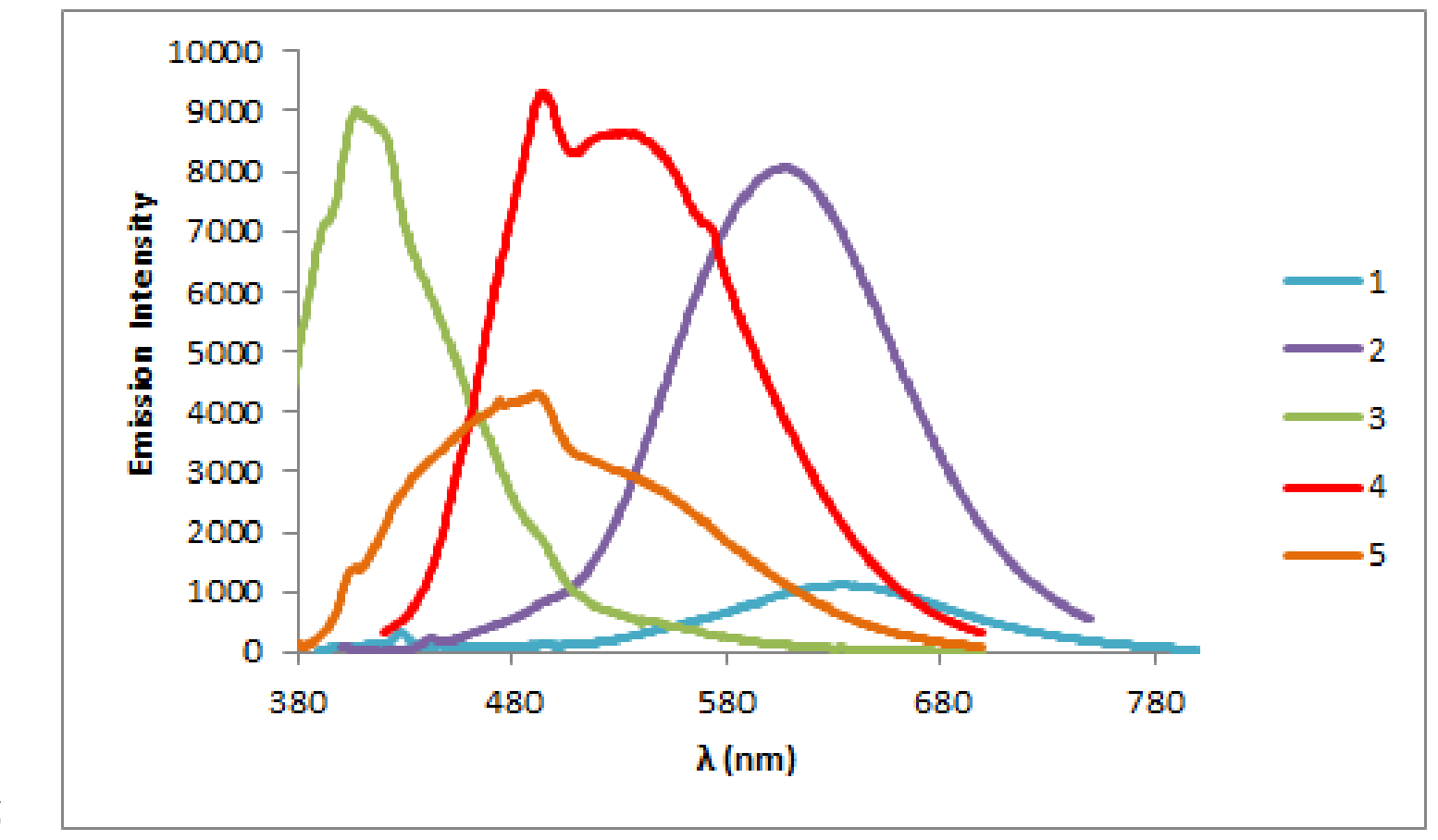

6 Figure 4: Photoluminescence spectra of compounds 1-5 in air equilibrated

7 dichloromethane solutions.

9 We believe that detailed spectroscopic and theoretical investigations

10 will be conducted in the future to unravel the properties of the excited

11 states involved in these processes in order to understand the fundamental

12 and crucial parameters to be controlled to lead to the discovery of very

13 useful molecules with panchromatic emission properties. 


\section{Conclusion}

3 In this work we set up general procedures to prepare two families of

4 betaine like molecules based on benzimidazole or pyrimidine cores.

5 Heating 2-chlorobenzimidazole or 2-bromopyrimidine with an excess

6 of the corresponding pyridine (pyridine, 4-tert-butylpyridine, 4-

7 hydroxypyridine, 4-trifluoroboratepyridine $\quad$ or 4 -

8 dimethylaminopyridine) in acetonitrile or dimethylsulfoxyde provides

9 the target molecules in good to high yields. Identification of the

10 compound was unambiguously achieved by spectroscopic methods

11 and the molecular weight was confirmed by mass analyses.

12 Furthermore, we have reported the UV-Vis. Absorption and emission

13 properties of the new molecules $\mathbf{1 - 1 0}$. Compounds of the pyrimidine

14 core family are not emissive in air equilibrated dichloromethane

15 solutions nor in the solid state but interesting photoluminescence

16 results are obtained for the benzimidazole-based family (1-5). In

17 particular some of the molecules clearly show a dual emission

18 behaviour that make them emitting nearly over the whole visible

19 spectral range providing a unique opportunity to design single-

20 component white light emitting materials with great potential in the

21 lighting technology. As an interesting perspective we believe that 
1 these novel betainoid molecules may act as singular bidentate

2 pyridylidene ligands for transition metal complexes. We will

3 investigate their coordination properties in the near future and the

4 results will be published in due course.

\section{Experimental}

6 Materials and Methods

7 All experimental manipulations were carried out under an argon 8 atmosphere by using Schlenk tube techniques. Solvents were dried and 9 distilled under argon by standard procedures. All reagents obtained from

10 commercial sources were used as received. The ${ }^{1} \mathrm{H}$ and ${ }^{13} \mathrm{C}$ NMR spectra

11 were recorded in $\mathrm{CD}_{3} \mathrm{CN}$ using a Bruker Avance 300 NMR spectrometer at

$12300.13 \mathrm{MHz}$, and $75.47 \mathrm{MHz}$ respectively. IR spectra were recorded on a

13 Bruker Tensor 27 equipped with an ATR Harricks apparatus. UV-Vis.

14 spectra were recorded on a JASCO V-670 Spectrometer.

15 Photoluminescence spectra were recorded using a JASCO J-815 CD

16 Spectrometer. Mass spectrometric analyses of compounds 2, 4, 5, 7, 9, and

$17 \mathbf{1 0}$ were performed on a microTOF Bruker mass spectrometer (ESI-TOF).

18 These compounds were performed in methanol by direct infusion with the

19 ESI-source set at $180^{\circ} \mathrm{C}$ and a capillary voltage set at 4500 VMass

20 spectrometric analyses of compounds $\mathbf{3 , 8}$ and $\mathbf{6}$ were performed on a LTQ

21 Orbitrap high-resolution (Thermo). These compounds were dissolved in 
1 methanol and analyzed by direct infusion with the positive mode

2 Electrospray (ESI) source set at $275^{\circ} \mathrm{C}$ and a capillary voltage set at $20 \mathrm{~V}$.

4 Compound 1, 2-pyridiniumbenzimidazolate: 2-chlorobenzimidazole (250

$5 \mathrm{mg}, 1,64 \mathrm{mmol})$ and anhydrous pyridine $(1 \mathrm{~mL})$ were placed in a Schlenk

6 tube and acetonitrile $(20 \mathrm{ml})$ was added. The mixture was refluxed under an

7 atmosphere of argon at $100{ }^{\circ} \mathrm{C}$ for $48 \mathrm{~h}$. Then cooling the solution results in

8 the precipitation of unreacted 2-chlorobenzimidazole as white crystalline

9 needles that can be recovered on a sintered glass funnel. The filtrate is then

10 evaporated to dryness and to the oily residue is added anhydrous diethyl

11 ether $(50 \mathrm{~mL})$, a light-yellow solid formed and was recovered and

12 dissolved in methanol in presence of $\mathrm{Cs}_{2} \mathrm{CO} 3$ for 30 minutes. After

13 evaporation to dryness, the solid residue was extracted with

14 dichloromethane $(3 \times 15 \mathrm{~mL})$, upon filtration through celite and evaporation

15 of the volatiles; a yellow solid is obtained (288 mg, 1,47 mmol). Yield: 89 $16 \%$.

17 IR (neat ATR Harricks, $\mathrm{cm}^{-1}$ ): 3064, 2923, 1683, 1627, 1524, 1481, $181434,1352,1334,1315,1269,1158,1072,1040,952,879,856,813,742$, $19674,615,595,551,522,503,429,376,357,309$. 
$1 \quad{ }^{1} \mathrm{H}$ NMR $\left(300.13 \mathrm{MHz}, \mathrm{CD}_{3} \mathrm{CN}\right): \delta=10.00\left(\mathrm{~d}, 2 \mathrm{H},{ }^{2} J=6.9 \mathrm{~Hz}, \mathrm{H}_{\alpha}\right.$

2 pyridinium), $8.42\left(\mathrm{t}, 1 \mathrm{H},{ }^{2} \mathrm{~J}=7 \mathrm{~Hz}, \mathrm{H}_{\beta}\right.$ pyridinium), $8.03\left(\mathrm{dd}, 2 \mathrm{H},{ }^{2} J=7\right.$

$3 \mathrm{~Hz}, \mathrm{H}_{\beta}$ pyridinium), $7.54\left(\mathrm{dd}, 2 \mathrm{H},{ }^{2} J=9.0 \mathrm{~Hz},{ }^{3} J_{\mathrm{H}-\mathrm{H}}=2.7 \mathrm{~Hz}, \mathrm{H}_{\beta}\right.$

4 benzimidazol), $7.04\left(\mathrm{dd}, 2 \mathrm{H},{ }^{2} J=9.0 \mathrm{~Hz},{ }^{3} J_{\mathrm{H}-\mathrm{H}}=2.7 \mathrm{~Hz}, \mathrm{H}_{\alpha}\right.$ benzimidazol).

$5{ }^{13} \mathrm{C}\left\{-{ }^{1} \mathrm{H}\right\}$ NMR $\left(75.47 \mathrm{MHz}, \mathrm{DMSO}-d_{6}\right) \delta=124.4,128.1,141.8,145.3$,

$6 \quad 149.1,150.9$.

7

Anal. Calcd. For $\mathrm{C}_{12} \mathrm{H}_{9} \mathrm{~N}_{3}\left(195.2\right.$ g.mol $\left.{ }^{-1}\right): \mathrm{C}, 73.83 ; \mathrm{H}, 4.65 ; \mathrm{N}$,

$8 \quad$ 21.52. Found: C, 74.31; H, 4.37; N, 21.11.

9

10 Compound 2, 2-4-tert-butylpyridiniumbenzimidazolate: 2-

11 chlorobenzimidazole (540 $\mathrm{mg}, 3,54 \mathrm{mmol})$ and anhydrous 4-tert-

12 butylpyridyl $(1 \mathrm{~mL})$ were placed in a Schlenk tube and acetonitrile $(20 \mathrm{ml})$

13 was added. The mixture was refluxed overnight under an argon atmosphere

14 at $100{ }^{\circ} \mathrm{C}$. Then cooling the solution resulted in the precipitation of

15 unreacted 2-chlorobenzimidazole as white crystalline needles that can be

16 recovered on a sintered glass funnel. The filtrate is then evaporated to

17 dryness and to the oily residue is added anhydrous diethyl ether $(50 \mathrm{~mL})$,

18 this precipitate and anhydrous $\mathrm{Cs}_{2} \mathrm{CO}_{3}(219 \mathrm{mg})$ were placed in a Schlenk

19 tube and methanol $(20 \mathrm{ml})$ was added. The mixture was stirred under an

20 atmosphere of argon at room temperature for two hours. The solvent is then 
1 evaporated under reduced pressure. The residue is extracted with

2 dichloromethane $(50 \mathrm{~mL})$, compound 2 is obtained as a yellow crystalline

3 solid (553 mg, 2,2 mmol). Yield: $62 \%$.

4 IR (neat ATR Harricks, $\mathrm{cm}^{-1}$ ): 3420, 3026, 2958, 1632, 1608, 1555, $51497,1465,1445,1393,1366,1306,1267,1193,1123,1104,1044,1001$, $6963,868,810,737,667,622,566,451,415$.

${ }^{1} \mathrm{H}$ NMR (300.13 MHz, DMSO): $\delta=9.86\left(\mathrm{~d}, 2 \mathrm{H},{ }^{2} J=6.9 \mathrm{~Hz}, \mathrm{H}_{\alpha}\right.$ 8 pyridynium), $8.16\left(\mathrm{~d}, 2 \mathrm{H},{ }^{2} J=6.9 \mathrm{~Hz}, \mathrm{H}_{\beta}\right.$ pyridynium $), 7.48\left(\mathrm{dd}, 2 \mathrm{H},{ }^{2} J=\right.$ $99.0 \mathrm{~Hz},{ }^{3} J_{\mathrm{H}-\mathrm{H}}=2.7 \mathrm{~Hz}, \mathrm{H}_{\beta}$ benzimidazol $), 6.95\left(\mathrm{dd}, 2 \mathrm{H},{ }^{2} J=9.0 \mathrm{~Hz},{ }^{3} J_{\mathrm{H}-\mathrm{H}}=\right.$

$102.7 \mathrm{~Hz}, \mathrm{H}_{\alpha}$ benzimidazol), 1.42 (s, 9H, $\mathrm{CH}_{3}$ tert-butyl). ${ }^{13} \mathrm{C}\left\{-{ }^{1} \mathrm{H}\right\}$ NMR $11\left(75.47 \mathrm{MHz}, \mathrm{DMSO}-d_{6}\right) \delta=30.0,36.7,117.8,119.9,125.1,138.8,146.9$, 12170.1. HRMS - m/z calcd. for $\left[\mathrm{C}_{16} \mathrm{H}_{18} \mathrm{~N}_{3}+\mathrm{H}\right]^{+}$252.1495; found. 252.1505 . Anal. Calcd. For $\mathrm{C}_{16} \mathrm{H}_{17} \mathrm{~N}_{3}\left(251.33\right.$ g.mol $\left.{ }^{-1}\right)$ : C, 76.46; H, 4.82; N,

15 16.72. Found: C, 75.98; H, 6.49; N, 17.15.

16 Compound 3, 2-4- $N$-pyridinone-1H-benzimidazole:

17 chlorobenzimidazole ( $250 \mathrm{mg}, 1,64 \mathrm{mmol})$, with sodium carbonate (190 $18 \mathrm{mg}, 0.59 \mathrm{mmol})$ and anhydrous hydroxypyridine (170 $\mathrm{mg}, 1,79 \mathrm{mmol})$ 19 were placed in a Schlenk tube and dimethyl sulfoxide (2 ml) was added. 20 The mixture was heated under an atmosphere of argon at $140{ }^{\circ} \mathrm{C}$ for $24 \mathrm{~h}$. 
1 The solvent is evaporated under vacuum, and the product is precipitated by

2 addition of $30 \mathrm{ml}$ of DCM. The mixture is then sintered from porosity 4 3 and then washed with $2 \times 15 \mathrm{~mL}$ diethyl ether. A brownish solid is obtained 4 (145 mg, $0.64 \mathrm{mmol})$. Yield: $42 \%$. IR (neat ATR Harricks, $\mathrm{cm}^{-1}$ ): 3718, 3276, 2934, 2811, 1638, 1573, $61491,1417,1337,1264,1178,1125,1014,864,808,739,625,539,491$, $7460,440$.

${ }^{1} \mathrm{H}$ NMR (300.13 MHz, DMSO): $\delta=8.46\left(\mathrm{~d}, 2 \mathrm{H},{ }^{2} J=6.9 \mathrm{~Hz}, \mathrm{H}_{\alpha}\right.$

9 pyridone), $7.58\left(\mathrm{dd}, 2 \mathrm{H},{ }^{2} J=9.0 \mathrm{~Hz},{ }^{3} J_{\mathrm{H}-\mathrm{H}}=2.7 \mathrm{~Hz}, \mathrm{H}_{\beta}\right.$ benzimidazol $), 7.25$

$10\left(\mathrm{dd}, 2 \mathrm{H},{ }^{2} J=9.0 \mathrm{~Hz},{ }^{3} J_{\mathrm{H}-\mathrm{H}}=2.7 \mathrm{~Hz}, \mathrm{H}_{\alpha}\right.$ benzimidazol $), 6.39\left(\mathrm{~d}, 2 \mathrm{H},{ }^{2} J=\right.$

$116.36 \mathrm{~Hz}, \mathrm{H}_{\square}$ pyridone). ${ }^{13} \mathrm{C}\left\{-{ }^{1} \mathrm{H}\right\}$ NMR $\left(75.47 \mathrm{MHz}\right.$, DMSO- $\left.d_{6}\right) \square=115.5$, $12 \quad 118.5,123.0,137.0,138.1,147.4,178.9$.

13 HRMS - m/z calcd. for $\left[\mathrm{C}_{12} \mathrm{H}_{9} \mathrm{~N}_{3} \mathrm{O}+\mathrm{Na}\right]^{+} 234.0638$, found: 234.0638 Anal. Calcd. For $\mathrm{C}_{12} \mathrm{H}_{9} \mathrm{~N}_{3} \mathrm{O}$ (211.2 g. $\left.\mathrm{mol}^{-1}\right)$ : C, 68.24; H, 4.29; N, 15 19.89. Found: C, 68.57; H, 4.13; N, 20.22.

16 Compound 4, 2-4-tetrafluoroboratopyridinium-1H-benzimidazole:

17 Potassium pyridine-4-trifluoroborate $(365 \mathrm{mg}, 1.97 \mathrm{mmol})$ is added in 18 excess to 2-chlorobenzimidazole (250 $\mathrm{mg}, 1.64 \mathrm{mmol})$ in DMSO (2 mL).

19 The mixture is stirred under reflux $\left(120^{\circ} \mathrm{C}\right)$ overnight. The solvent is 20 evaporated under vacuum, and the product is precipitated by addition of 30 
$1 \mathrm{ml}$ of diethyl ether. The mixture is then filtered on sintered porosity is 4 and

2 then washed with $2 \times 15 \mathrm{~mL} \mathrm{Et}_{2} \mathrm{O}$. A purple-black solid is obtained (407 mg,

$31.55 \mathrm{mmol})$. Yield: $95 \%$.

$4 \quad$ IR (neat ATR Harricks, $\mathrm{cm}^{-1}$ ): 3212, 3119, 2867, 2748, 1626, 1552,

$51530,1500,1470,1444,1415,1338,1318,1263,1201,1178,1112,1019$,

$6977,950,836,748,732,664,635,615,571,556,532,480,429,380,338$.

${ }^{1} \mathrm{H}$ NMR (300.13 MHz, DMSO): $\delta=9.44\left(\mathrm{~d}, 2 \mathrm{H},{ }^{2} J=6.9 \mathrm{~Hz}, \mathrm{H}_{\alpha}\right.$

8 pyridynium), $8.18\left(\mathrm{~d}, 2 \mathrm{H},{ }^{2} J=6.36 \mathrm{~Hz}, \mathrm{H}_{\beta}\right.$ pyridynium $) ; 7.75\left(\mathrm{dd}, 2 \mathrm{H},{ }^{2} J=\right.$

$99.0 \mathrm{~Hz},{ }^{3} J_{\mathrm{H}-\mathrm{H}}=2.7 \mathrm{~Hz}, \mathrm{H}_{\beta}$ benzimidazol $), 7.40\left(\mathrm{dd}, 2 \mathrm{H},{ }^{2} J=9.0 \mathrm{~Hz},{ }^{3} J_{\mathrm{H}-\mathrm{H}}=\right.$

$102.7 \mathrm{~Hz}, \mathrm{H}_{\alpha}$ benzimidazol). ${ }^{13} \mathrm{C}\left\{-{ }^{1} \mathrm{H}\right\}$ NMR $\left(75.47 \mathrm{MHz}\right.$, DMSO- $\left.d_{6}\right) \delta=$ $11 \quad 116.2,123.1,129.9,137.9,138.6,145.9$. HRMS - $\mathrm{m} / \mathrm{z}$ calcd. for $\left[\mathrm{C}_{12} \mathrm{H}_{8} \mathrm{~N}_{3} \mathrm{BF}_{3}-\mathrm{H}\right]^{+}$262.0771; found: 13262.0761. Anal. Calcd. For $\mathrm{C}_{12} \mathrm{H}_{9} \mathrm{BF}_{3} \mathrm{~N}_{3}\left(263.0\right.$ g.mol $\left.{ }^{-1}\right)$ : C, 54.80; H, 3.45; N, 15 15.98. Found: C, 55.17; H, 3.98; N, 16.31.

17 Compound 5, 2-4-N,N-dimethylaminopyridiniumbenzimidazole: 218 chlorobenzimidazole (250 $\mathrm{mg}, 1.64 \mathrm{mmol}$ ), and 4-dimethylaminopyridine 19 (250 mg, 2.04) were placed in a Schlenk tube and dimethyl sulfoxide (2 $20 \mathrm{ml}$ ) was added. The mixture was heated under an atmosphere of argon at 
$1 \quad 140{ }^{\circ} \mathrm{C}$ for $24 \mathrm{~h}$. The solvent is evaporated under vacuum, and the product is 2 precipitated by addition of $30 \mathrm{ml}$ of diethyl ether. The mixture is then 3 filtered on sintered porosity is 4 and then washed with $2 \times 15 \mathrm{~mL} \mathrm{Et}_{2} \mathrm{O}$. This 4 precipitate and anhydrous $\mathrm{Na}_{2} \mathrm{CO}_{3}(120 \mathrm{mg})$ were placed in a Schlenk tube 5 and methanol $(20 \mathrm{ml})$ was added. The mixture was stirred under an 6 atmosphere of argon at room temperature for two hours. The solvent is then 7 evaporated under reduced pressure. The residue is extracted with 8 dichloromethane $(50 \mathrm{~mL})$. Compound 5 is obtained as a yellow crystalline 9 solid (260 mg, $0.95 \mathrm{mmol})$. Yield: $58 \%$. IR (neat ATR Harricks, $\mathrm{cm}^{-1}$ ): 1649, 1582, 1536, 1434, 1410, 1270, $111220,1125,1103,1004,955.817,750,628,537,495,446,366,306$. ${ }^{1} \mathrm{H}$ NMR (300.13 MHz, DMSO): $\delta=9.24\left(\mathrm{~d}, 2 \mathrm{H},{ }^{2} J=6.9 \mathrm{~Hz}, \mathrm{H}_{\alpha}\right.$ 13 pyridynium), $7.37\left(\mathrm{dd}, 2 \mathrm{H},{ }^{2} J=9.0 \mathrm{~Hz},{ }^{3} J_{\mathrm{H}-\mathrm{H}}=2.7 \mathrm{~Hz}, \mathrm{H}_{\beta}\right.$ benzimidazol), $147.13\left(\mathrm{~d}, 2 \mathrm{H},{ }^{2} J=6.4 \mathrm{~Hz}, \mathrm{H}_{\beta}\right.$ pyridynium $), 6.85\left(\mathrm{dd}, 2 \mathrm{H},{ }^{2} J=9.0 \mathrm{~Hz},{ }^{3} J_{\mathrm{H}-\mathrm{H}}=\right.$ $152.7 \mathrm{~Hz}, \mathrm{H}_{\alpha}$ benzimidazol), 3.28 (s, $6 \mathrm{H}, \mathrm{CH}_{3}$ pyridynium). ${ }^{13} \mathrm{C}\left\{-{ }^{1} \mathrm{H}\right\} \mathrm{NMR}$ $16\left(75.47 \mathrm{MHz}, \mathrm{DMSO}-d_{6}\right) \delta=40.4,107.8,115.5,122.6,137.6,138.5,146.7$, $17 \quad 156.7$. HRMS - m/z calcd. For: $\left[\mathrm{C}_{14} \mathrm{H}_{15} \mathrm{~N}_{4+} \mathrm{H}\right]^{+}$239.1291; calc. 239.1295. Anal. Calcd. For $\mathrm{C}_{14} \mathrm{H}_{14} \mathrm{~N}_{4}$ (238.3 g. $\left.\mathrm{mol}^{-1}\right)$ : C, 70.57; H, 5.92; N, 20 23.51. Found: C, 70.05; H, 6.07; N, 23.79. 
2 Compound 6, 2-pyridiniumpyrimidine bromide: 2-bromopyrimidine (250

$3 \mathrm{mg}, 1.58 \mathrm{mmol})$ and anhydrous pyridine $(0.15 \mathrm{~mL})$ were placed in a 4 Schlenk tube and dimethyl sulfoxide $(2 \mathrm{ml})$ was added. The mixture was

5 refluxed under an atmosphere of argon at $120{ }^{\circ} \mathrm{C}$ for $24 \mathrm{~h}$. The solvent is 6 evaporated under vacuum, and the product is precipitated by addition of 30

$7 \mathrm{ml}$ of diethyl ether. The mixture is then filtered on sintered porosity is 4 and 8 then washed with diethylether $(2 \times 15 \mathrm{~mL})$. Compound $\mathbf{6}$ is obtained as a 9 dark crystalline solid (370 mg, $1.56 \mathrm{mmol}$ ). Yield: $99 \%$.

10 IR (neat ATR Harricks, $\mathrm{cm}^{-1}$ ): 3129, 3041, 2990, 1624, 1592, 1560, $111481,1451,1407,1286,1193,1041,996,858,808,772,674,648,627$, 12493.

${ }^{1} \mathrm{H}$ NMR $\left(300.13 \mathrm{MHz}, \mathrm{CD}_{3} \mathrm{CN}\right): \delta=10.00\left(\mathrm{dd}, 2 \mathrm{H},{ }^{2} J=6.9 \mathrm{~Hz}, \mathrm{H}_{\alpha}\right.$ 14 pyridynium), $9.12\left(\mathrm{~d}, 2 \mathrm{H},{ }^{2} J=9.0 \mathrm{~Hz},{ }^{3} J_{\mathrm{H}-\mathrm{H}}=2.7 \mathrm{~Hz}, \mathrm{H}_{\alpha}\right.$ pyrimidine $), 8.87$ 15 (tt, $2 \mathrm{H}, \mathrm{H}_{\beta}$ pyridynium), $8.33\left(\mathrm{t}, 1 \mathrm{H}, \mathrm{H}_{\beta}\right.$ pyrimidyne), $7.88\left(\mathrm{t}, 1 \mathrm{H}, \mathrm{H}_{\delta}\right.$ 16 pyrimidine). ${ }^{13} \mathrm{C}\left\{-{ }^{1} \mathrm{H}\right\}$ NMR (75.47 MHz, DMSO- $\left.d_{6}\right) \delta=124.4,128.5$, $17 \quad 141.7,150.7,160.9$. HRMS - m/z calcd. for: $\left[\mathrm{C}_{9} \mathrm{H}_{8} \mathrm{~N}_{3}\right]^{+} 158.0713$, found: 158.0712 Anal. Calcd. For $\mathrm{C}_{9} \mathrm{H}_{8} \mathrm{BrN}_{3}\left(238.1\right.$ g.mol $\left.{ }^{-1}\right)$ : C, 45.40; H, 3.39; N, 20 17.65. Found: C, 45.91; H, 3.88; N, 18.03. 
2 Compound 7, 2-4-tert-butylpyridiniumpyrimidine bromide: 2-

3 bromopyrimidine (1 g, $6.3 \mathrm{mmol})$ and anhydrous 4-tert-butylpyridyl (1.5

$4 \mathrm{~mL})$ were placed in a Schlenk tube and acetonitrile $(20 \mathrm{ml})$ was added. The

5 mixture was refluxed under an atmosphere of argon at $100{ }^{\circ} \mathrm{C}$ for $48 \mathrm{~h}$. The

6 solvent is evaporated under vacuum, and the product is precipitated by

7 addition of $30 \mathrm{ml}$ of diethyl ether. The mixture is then filtered on sintered

8 porosity is 4 and then washed with $2 x 15 \mathrm{~mL}$ diethylether. Compound 7 is

9 obtained as a white crystalline solid (1.3 g, $4.43 \mathrm{mmol})$. Yield: $68 \%$.

10 IR (neat ATR Harricks, $\mathrm{cm}^{-1}$ ): 3012, 2964, 1634, 1590, 1556, 1499,

$111437,1402,1370,1291,1205,1127,1109,1094,1054,994,841,789,739$,

$12708,663,630,574,518,489,448$.

${ }^{1} \mathrm{H}$ NMR (300.13 MHz, DMSO): $\delta=9.88\left(\mathrm{~d}, 2 \mathrm{H},{ }^{2} J=6.9 \mathrm{~Hz}, \mathrm{H}_{\alpha}\right.$

14 pyridynium), $9.23\left(\mathrm{~d}, 2 \mathrm{H},{ }^{2} J=9.0 \mathrm{~Hz}, \mathrm{H}_{\alpha}\right.$ pyrimidine $), 8.40\left(\mathrm{~d}, 2 \mathrm{H},{ }^{2} J=6.9\right.$

$15 \mathrm{~Hz}, \mathrm{H}_{\beta}$ pyridynium), 7.98 ( $\mathrm{t}, 1 \mathrm{H}, \mathrm{H}_{\beta}$ pyrimidine), $1.46\left(\mathrm{~s}, 9 \mathrm{H}, \mathrm{CH}_{3}\right.$ tert-

16 butyl). ${ }^{13} \mathrm{C}\left\{-{ }^{1} \mathrm{H}\right\}$ NMR (75.47 MHz, DMSO- $\left.d_{6}\right) \delta=207.2,175.5,160.8$,

$17 \quad 155.8,140.9,125.4,124.2,37.4,30.3$. Anal. Calcd. For $\mathrm{C}_{13} \mathrm{H}_{16} \mathrm{BrN}_{3}\left(294.2\right.$ g.mol $\left.{ }^{-1}\right)$ : C, 53.07; H, 5.48; N, 20 14.28. Found: C, 52.79; H, 5.18; N, 14.81. 
Compound 8, 2-4- $N$-pyridinonepyrimidine: 2-bromopyrimidine

3 (250 mg, 1,58 mmol), with sodium carbonate $(160 \mathrm{mg})$ and anhydrous 4 hydroxypyridine $(150 \mathrm{mg}, 1.1 \mathrm{eq})$ were placed in a Schlenk tube and 5 dimethyl sulfoxide $(2 \mathrm{ml})$ was added. The mixture was refluxed under an 6 atmosphere of argon at $140{ }^{\circ} \mathrm{C}$ for $24 \mathrm{~h}$. The solvent is evaporated under 7 vacuum, and the product is precipitated by addition of $30 \mathrm{ml}$ of 8 dichloromethane. The mixture is then sintered from porosity 4 and then 9 washed with $2 \times 15 \mathrm{~mL} \mathrm{Et}_{2} \mathrm{O}$. A black purple solid is obtained (210 mg, 1,21 $10 \mathrm{mmol})$.

11 Yield: $77 \%$.

12 IR (neat ATR Harricks, $\mathrm{cm}^{-1}$ ): 3081, 1634, 1593, 1578, 1565, 1545, $131436,1395,1347,1314,1183,1104,1084,1040,849,830,791,721,649$, $14627,585,538,451,418,375,321$.

${ }^{1} \mathrm{H}$ NMR (300.13 MHz, DMSO): $\delta=9.02\left(\mathrm{~d}, 2 \mathrm{H},{ }^{2} J=6.9 \mathrm{~Hz}, \mathrm{H}_{\alpha}\right.$ 16 pyridynium), $8.96\left(\mathrm{~d}, 2 \mathrm{H},{ }^{2} J=9.0 \mathrm{~Hz},{ }^{3} J_{\mathrm{H}-\mathrm{H}}=2.7 \mathrm{~Hz}, \mathrm{H}_{\alpha}\right.$ pyrimidyne), $)$,

$177.60\left(\mathrm{t}, 1 \mathrm{H}, \mathrm{H}_{\beta}\right.$ pyrimidyne), $6.60\left(\mathrm{~d}, 2 \mathrm{H},{ }^{2} J=6.9 \mathrm{~Hz}, \mathrm{H}_{\beta}\right.$ pyridynium $)$. $18{ }^{13} \mathrm{C}\left\{-{ }^{1} \mathrm{H}\right\}$ NMR $\left(75.47 \mathrm{MHz}, \mathrm{DMSO}-d_{6}\right) \delta=178.1,159.6,154.9,136.8$, $19 \quad 120.2,117.0$, HRMS - m/z calcd. for $\left[\mathrm{C}_{9} \mathrm{H}_{7} \mathrm{~N}_{3} \mathrm{O}+\mathrm{Na}\right]^{+}$196.0481, found: 196.0483 . 


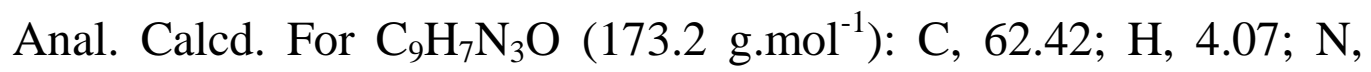

2 24.27. Found: C, 62.91; H, 3.95; N, 24.69.

Compound 9, 2-4-tetrafluoroboratopyridiniumpyrimidine:

5 Potassium pyridine-4-trifluoroborate $(322 \mathrm{mg}, 1.74)$ is added in excess to

6 2-bromopyrimidine $(250 \mathrm{mg}, 1.58 \mathrm{mmol})$ in DMSO $(2 \mathrm{~mL})$. The mixture is

7 stirred under reflux $\left(120^{\circ} \mathrm{C}\right)$ overnight. The solvent is evaporated under

8 vacuum, and the product is precipitated by addition of $30 \mathrm{ml}$ of diethyl

9 ether. The mixture is then filtered on sintered porosity is 4 and then washed

10 with $2 \times 15 \mathrm{~mL} \mathrm{Et}_{2} \mathrm{O}$. A black solid is obtained (316 mg, $1.40 \mathrm{mmol}$ ).

$11 \quad$ Yield: $89 \%$.

12 IR (neat ATR Harricks, $\mathrm{cm}^{-1}$ ): 2921, 1630, 1592, 1562, 1405, 1282,

$131187,1015,955,854,823,788,620,504,419,325$.

$14{ }^{1} \mathrm{H}$ NMR $\left(300.13 \mathrm{MHz}, \mathrm{DMSO}-d_{6}\right): \delta=9.71\left(\mathrm{~d}, 2 \mathrm{H},{ }^{2} J=6.9 \mathrm{~Hz}, \mathrm{H}_{\alpha}\right.$

15 pyridynium), $9.20\left(\mathrm{~d}, 2 \mathrm{H},{ }^{2} J=9.0 \mathrm{~Hz},{ }^{3} J_{\mathrm{H}-\mathrm{H}}=2.7 \mathrm{~Hz}, \mathrm{H}_{\alpha}\right.$ pyrimidyne $), 8.18$

$16\left(\mathrm{~d}, 2 \mathrm{H},{ }^{2} J=6.9 \mathrm{~Hz}, \mathrm{H}_{\beta}\right.$ pyridynium $), 7.92\left(\mathrm{t}, 1 \mathrm{H}, \mathrm{H}_{\beta}\right.$ pyrimidyne $) .{ }^{13} \mathrm{C}\left\{-{ }^{1} \mathrm{H}\right\}$

17 NMR (75.47 MHz, DMSO- $\left.d_{6}\right) \delta=123.97,130.34,138.19,155.70,160.69$.

19264.0318. 
Anal. Calcd. For $\mathrm{C}_{9} \mathrm{H}_{7} \mathrm{BF}_{3} \mathrm{~N}_{3}\left(225.0\right.$ g.mol$\left.{ }^{-1}\right)$ : C, 48.05; H, 3.14; N,

$2 \quad$ 18.68. Found: C, 48.47; H, 2.98; N, 19.01.

4 Compound 10, 2-4-N,N-dimethylaminopyridiniumpyrimidine bromide: 2-

5 bromopyrimidine $(250 \mathrm{mg}, 1.56 \mathrm{mmol})$ and 4-dimethylaminopyridine (382

$6 \mathrm{mg}, 3.13 \mathrm{mmol})$ were placed in a Schlenk tube and acetonitrile $(20 \mathrm{ml})$ was

7 added. The mixture was refluxed under an atmosphere of argon at $100{ }^{\circ} \mathrm{C}$

8 for $48 \mathrm{~h}$. The solvent is evaporated under vacuum, and the product is

9 precipitated by addition of $30 \mathrm{ml}$ of diethyl ether. The mixture is then

10 filtered and washed with $2 \times 15 \mathrm{~mL}$ Et2O. Compound $\mathbf{1 0}$ is obtained as a

11 whit crystalline solid (214mg, $0.765 \mathrm{mmol})$.

Yield: $49 \%$.

IR (neat ATR Harricks, $\mathrm{cm}^{-1}$ ): 3447, 3407, 3072, 1641, 1580, 1560,

$141439,1409,1385,1343,1327,1306,1225,1195,1089,1047,941,830$,

$15787,725,662,630,574,536,516,479,446$.

${ }^{1} \mathrm{H}$ NMR $\left(300.13 \mathrm{MHz}, \mathrm{DMSO}-d_{6}\right): \delta=9.21\left(\mathrm{~d}, 2 \mathrm{H},{ }^{2} \mathrm{~J}=6.9 \mathrm{~Hz}, \mathrm{H}_{\alpha}\right.$

17 pyridynium), $9.06\left(\mathrm{~d}, 2 \mathrm{H},{ }^{2} \mathrm{~J}=9.0 \mathrm{~Hz},{ }^{3} J_{\mathrm{H}-\mathrm{H}}=2.7 \mathrm{~Hz}, \mathrm{H}_{\alpha}\right.$ pyrimidyne $), 7.74$

$18\left(\mathrm{t}, 1 \mathrm{H}, \mathrm{H}_{\beta}\right.$ pyrimidyne), $7.28\left(\mathrm{~d}, 2 \mathrm{H},{ }^{2} \mathrm{~J}=6.9 \mathrm{~Hz}, \mathrm{H}_{\beta}\right.$ pyridynium), 3.40 (s,

$196 \mathrm{H}, \mathrm{CH}_{3}$ methyl). ${ }^{13} \mathrm{C}\left\{-{ }^{1} \mathrm{H}\right\}$ NMR $\left(75.47 \mathrm{MHz}, \mathrm{DMSO}-d_{6}\right) \delta=41.0,108.3$, $20121.9,137.2,154.9,158.0,160.3$. 
$1 \quad$ HRMS - m/z calcd. for $\left[\mathrm{C}_{11} \mathrm{H}_{13} \mathrm{~N}_{4}\right]^{+}$201.1140; found: 201.1135 . Anal. Calcd. For $\mathrm{C}_{11} \mathrm{H}_{13} \mathrm{~N}_{4}\left(281.1\right.$ g.mol $\left.{ }^{-1}\right)$ : C, 46.99; H, 4.66; N,

3 19.93. Found: C, 45.43; H, 4.25; N, 20.27.

4

\section{References}

6

7 1. Perrier A, Aloïse S, Pawlowska Z, Sliwa M, Maurel F, Abe J (2011)

$8 \quad$ Chem Phys Lett, 515:42

9 2. Aloïse S, Pawlowska Z, Poizat O, Buntinx G, Perrier A, Maurel F,

10 Ohkawa K, Kimoto A, Abe J (2014) Phys Chem Chem Phys 16:1460

11 3. Kharlanov V, Rettig W (2009) J. Phys. Chem. A, 113:10693

12 4. Mente S R, Maroncelli M (1999) J. Phys. Chem. B 103:7704

13 5. Reichardt C (1994) Chem. Rev. 94:2319

14 6. Abe J, Shirai Y (1996) J. Am. Chem. Soc. 118:4705. -582

15 7. Abe J, Shirai Y, Nemoto N, Miyata F, Nagase Y (1997) J. Phys. Chem.

16 B 101:576

17 8. Breslow R (1958) J. Am. Chem. Soc. 80:3719

18 9. Wanzlick H W, Schönherr H J (1968) Angew. Chem. Int. Ed. 7:141

19 10. Öfele K (1968) J. Organomet. Chem. 12:42

20 11. Igau A, Grutzmacher H, Bacereido A, Bertrand G (1988) J. Am. Chem. $21 \quad$ Soc. $110: 4781$ 
1 12. Arduengo III A J, Harlow R L, Kline M A (1991) J. Am. Chem. Soc.

$2 \quad 113: 361$

3 13. Bourissou D, Guerret O, Gabbai F P, Bertrand G (2000) Chem. Rev. $4 \quad 100: 39$

5 14. Stander-Grobler E, Schuster O, Heydenrych G, Cronje S, Tosh E, 6 Albrecht M, Frenking G, Raubenheimer H G (2010) Organometallics $7 \quad 29: 5821$

8 15. Roselló-Merino M, Díez J, Conejero S (2010) Chem. Commun. $9 \quad 46: 9247$

10 16. Hata K, Segawa Y, Itami K (2012) Chem. Commun. 48:6642

11 17. Moussa J, Freeman G, Williams J A G, Chamoreau L M, Herson P, 12 Amouri H (2016) Eur. J. Inorg. Chem. 761

13 18. Moussa J, Haddouche K, Chamoreau L M, Amouri H (2016) Dalton 14 Trans. $45: 12644$

15 19. Owen J S, Labinger J A, J E. Bercaw (2004) J. Am. Chem. Soc. $16 \quad 126: 8247$

17 20. Dreger A, Nieger M, Drafz M, Schmidt A (2012) Z. Naturforsch. $18 \quad 67 b: 359$

19 21. Alcalde E, Dinares I, Elguero J, Fayet J P, Vertut M C, Miravitlles C, 20 Molins E (1987) J. Org. Chem. 52:5009 
1 22. Xie Z, Chen C, Xu S, Li J, Zhang Y, Liu S, Xu J, Chi Z (2015) Angew.

$2 \quad$ Chem. Int. Ed. 54:7181

3 23. Yang Q Y, Lehn J M (2014) Angew. Chem. Int. Ed. 53:4572

4 24. Tu G L, Mei C Y, Zhou Q G, Cheng Y X, Geng Y H, Wang L X, Ma D

5 G, Jing X B, Wang F S (2006) Adv. Funct. Mater. 16:101;

6 25. Yan B P, Cheung C C C, Kui S C F, Xiang H F, Roy V A L, Xu S J,

$7 \quad$ Che C M (2007) Adv. Mater. 19:3599

8 26. D'Andrade B W, Holmes R J, Forrest S R (2004) Adv. Mater. 16:624 
<smiles></smiles><smiles></smiles><smiles>O=c1ccn(-c2nc3ccccc3[nH]2)cc1</smiles><smiles>[Sb]c1cc[n+](-c2nc3ccccc3[nH]2)cc1</smiles><smiles></smiles>

(1)
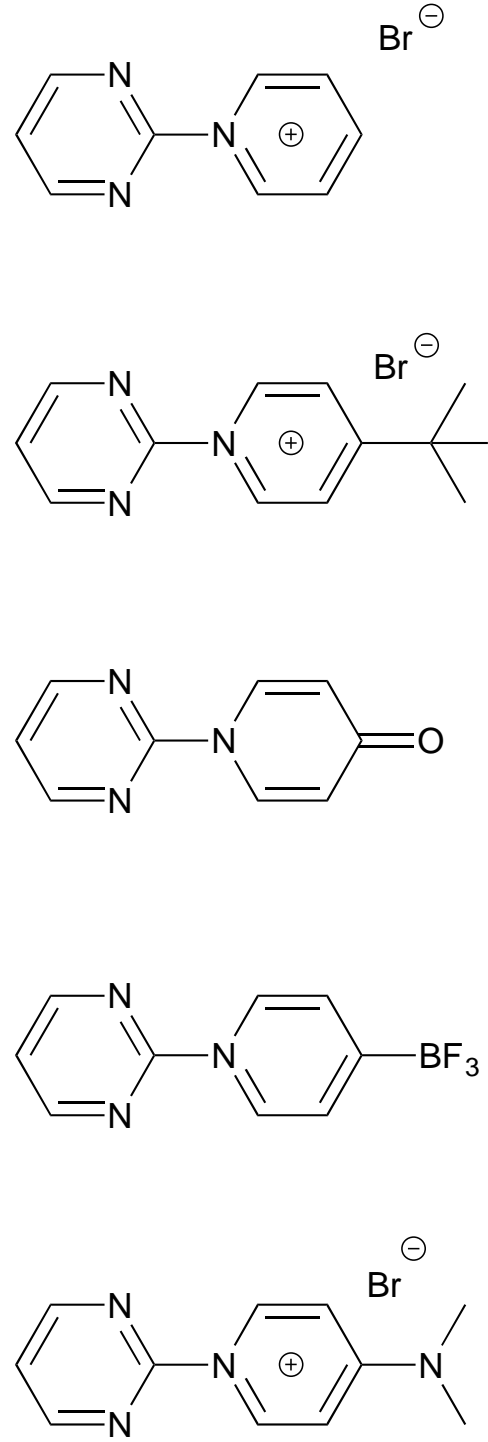<smiles>[Sb]c1cc[n+](-c2ncccn2)cc1</smiles>

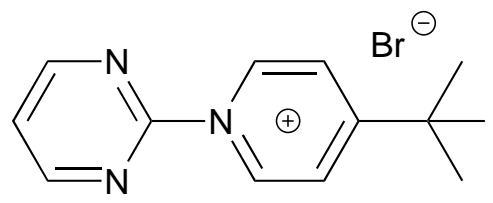

2 Figure 1: Novel pyridinium-benzimidazole and pyridinium-pyrimidine 3 scaffolds.

4 
<smiles>[R]c1ccncc1</smiles>

$\mathrm{R}=-\mathrm{H}, \mathrm{t}-\mathrm{Bu}, \mathrm{NMe}_{2}$
1) $\underset{\mathrm{CH}_{3} \mathrm{CN} / 100^{\circ} \mathrm{C}}{\longrightarrow} \mathrm{Cs} \mathrm{CO}_{3} / \mathrm{MeOH} / \mathrm{RT}$<smiles></smiles>

$R=-H(\mathbf{1}),-t-B u(2),-\mathrm{NMe}_{2}(\mathbf{5}$<smiles>[R]c1ccncc1</smiles>

2 Scheme 1: Synthesis of the pyridinium-betaine molecules with the 3 benzimidazole core $(\mathbf{1 - 5})$<smiles>[R]c1ccncc1</smiles>

$\left(\mathrm{Br}^{-}\right)$<smiles>[R]c1ccncc1</smiles>

$4 \mathrm{R}=-\mathrm{OH}\left(+\mathrm{Na}_{2} \mathrm{CO}_{3}\right),-\mathrm{BF}_{3}^{-}$

$$
\mathrm{R}==\mathrm{O}(\mathbf{8}),-\mathrm{BF}_{3^{-}}(\mathbf{9})
$$

5 Scheme 2: Synthetic routes to the novel compounds 6-10 based on

6 the pyrimidine core 


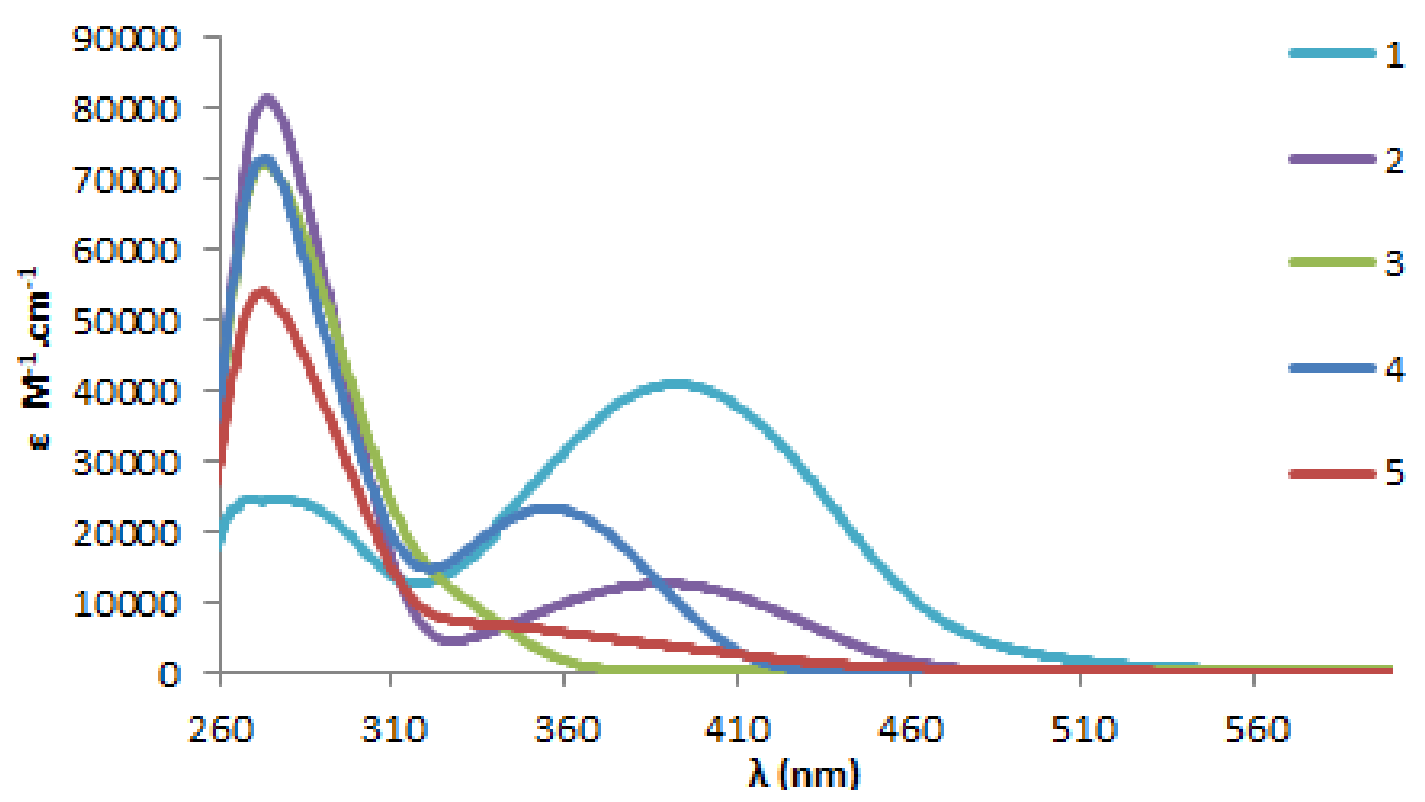

Figure 2: Absorption spectra of compounds 1-5 in acetonitrile

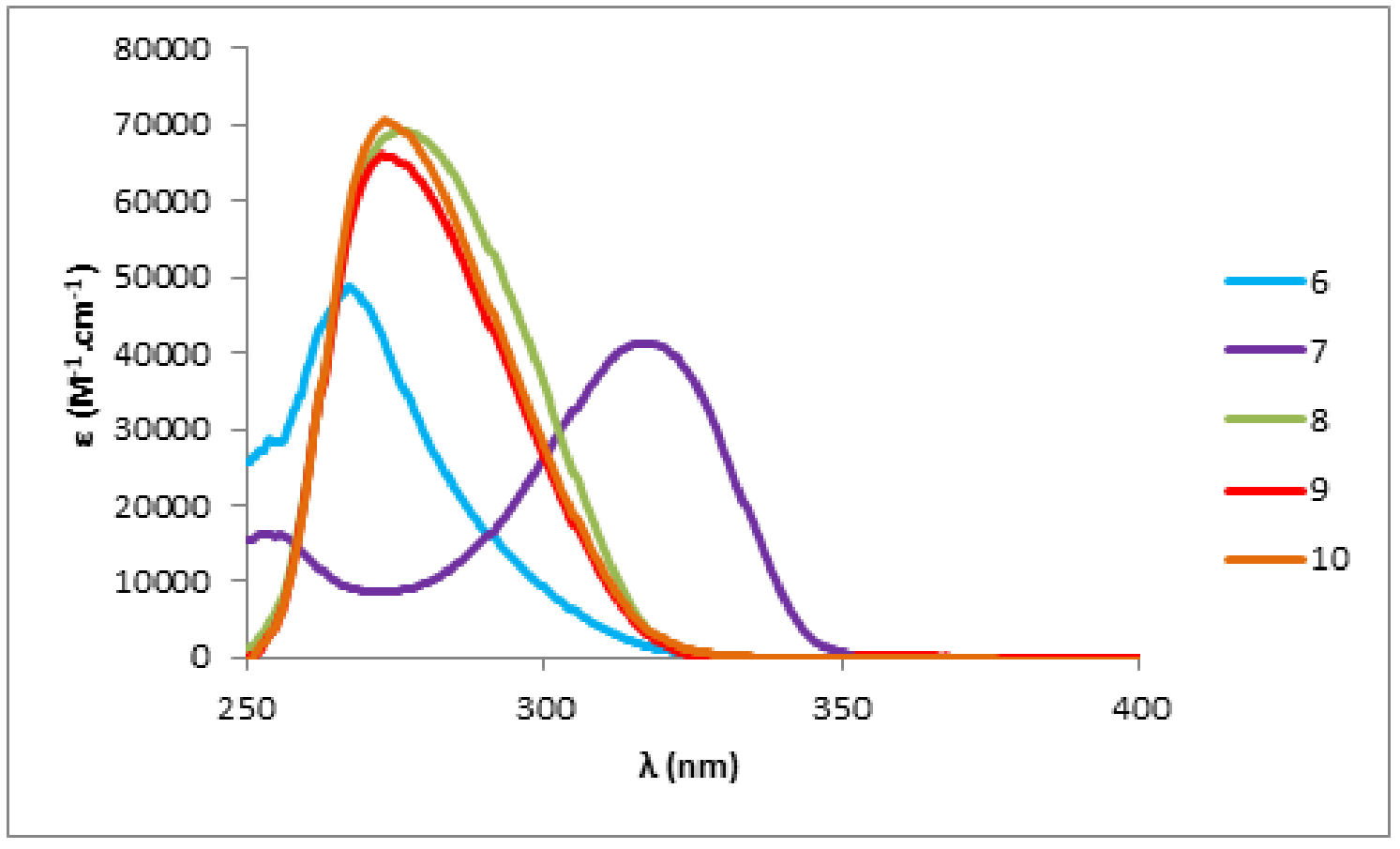

4 Figure 3: Absorption spectra of compounds 6-10 in acetonitrile

5

6 Table 1: UV-Vis. absorption data for compounds 1-10

\begin{tabular}{lll} 
& $\lambda_{\text {abs }}(\mathrm{nm})$ & $\varepsilon\left(\mathrm{mol}^{-1} . \mathrm{L}_{\mathrm{cm}} \mathrm{cm}^{-1}\right) \times 10^{4}$ \\
\hline $\mathbf{1}$ & $269 ; 392$ & $2.47 ; 4.09$ \\
$\mathbf{2}$ & $273 ; 388$ & $8.11 ; 1.27$
\end{tabular}




$\begin{array}{cll}\mathbf{3} & 273 & 7.21 \\ \mathbf{4} & 273 ; 355 & 7.29 ; 2.34 \\ \mathbf{5} & 272 & 5.39 \\ \mathbf{6} & 267 & 4.87 \\ \mathbf{7} & 317 & 4.13 \\ \mathbf{8} & 277 & 6.91 \\ \mathbf{9} & 273 & 6.59 \\ \mathbf{1 0} & 273 & 7.04\end{array}$

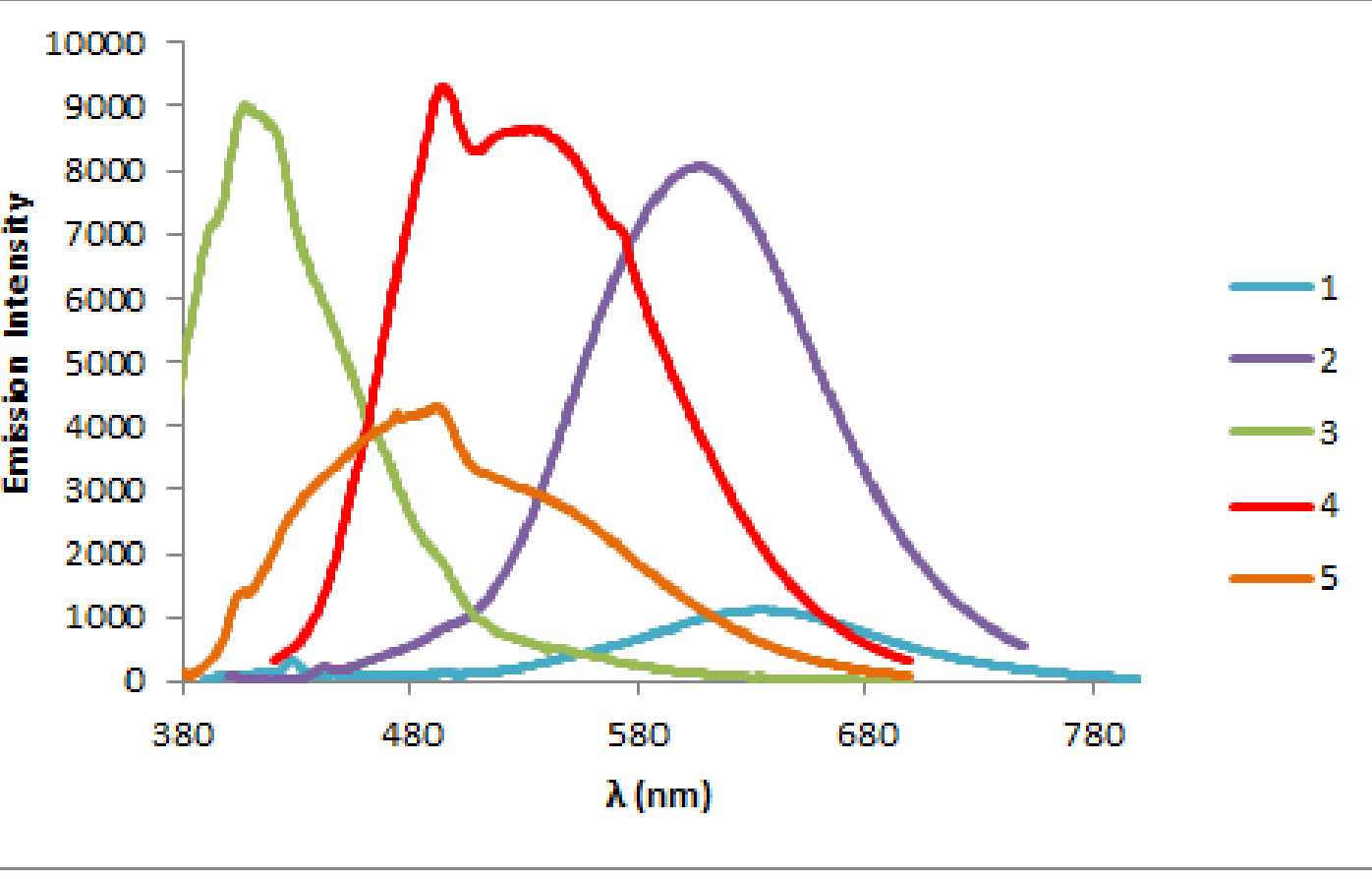

3 Figure 4: Photoluminescence spectra of compounds 1-5 in air equilibrated

4 dichloromethane solutions.

5

6 


\section{Graphical abstract}

2 A series of pyridinium-betaine like molecules has been reported. The title

3 compounds were prepared by mixing 2-chlorobenzimidazole or 2-

4 bromopyrimidine with the corresponding pyridines (pyridine, 4-tert-

5 butylpyridine, 4-hydroxypyridine, potassium 4-trifluoroboratepyridine, 4-

6 dimethylaminopyridine). Preliminary photoluminescence results showed

7 that some of the compounds could behave as single-component 8 panchromatic emitters.

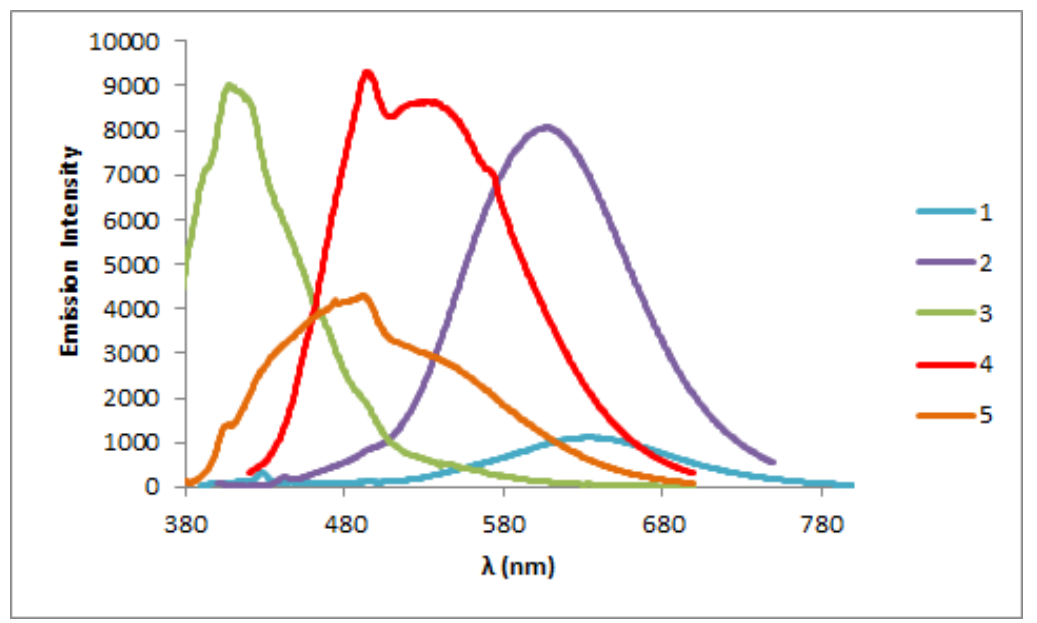

